\title{
Effect of Case Management Interventions for Patients with Substance Use Disorders: A Systematic Review
}

\author{
Louise Penzenstadler ${ }^{1 *}$, Ariella Machado', Gabriel Thorens ${ }^{1,2}$, Daniele Zullino ${ }^{1,2}$ \\ and Yasser Khazaal ${ }^{1,2,3}$
}

'Geneva University Hospitals, Geneva, Switzerland, ${ }^{2}$ Faculty of Medicine, Geneva University, Geneva, Switzerland,

${ }^{3}$ Research Center, Montreal University Institute of Mental Health, Montreal, QC, Canada

OPEN ACCESS

Edited by:

Sebastian von Peter,

Charité Universitätsmedizin

Berlin, Germany

Reviewed by:

Julian Schwarz,

Medizinische Hochschule

Brandenburg Theodor

Fontane, Germany

Dominique Isabelle Willard,

Centre hospitalier Sainte-Anne,

France

*Correspondence:

Louise Penzenstadler

louise.e.penzenstadler@hcuge.ch

Specialty section:

This article was submitted

to Public Mental Health,

a section of the journal

Frontiers in Psychiatry

Received: 04 January 2017

Accepted: 20 March 2017

Published: 06 April 2017

Citation:

Penzenstadler L, Machado A, Thorens G, Zullino D and Khazaal Y (2017) Effect of Case Management

Interventions for Patients with

Substance Use Disorders: A

Systematic Review.

Front. Psychiatry 8:51.

doi: 10.3389/fpsyt.2017.00051
Background: Substance use disorder (SUD) is an important health problem that requires a complex range of care because of the chronic nature of the disorder and the multiple psychosocial problems involved. Current outpatient programs often have difficulties in delivering and coordinating ongoing care and access to different healthcare providers. Various case management $(\mathrm{CM})$ models have been developed, first for patients in other psychiatric domains and then for patients with SUD, in order to improve treatment outcomes.

Aim: This paper aims to assess the effectiveness of CM for patients with SUD.

Methods: We performed a systematic review of CM interventions for patients with SUD by analyzing randomized controlled studies published on the subject between 1996 and 2016 found on the electronic database PubMed.

Results and conclusion: Fourteen studies were included in the analysis. Differences between studies in outcome measures, populations included, and intervention characteristics made it difficult to compare results. Most of these studies reported improvement in some of the chosen outcomes. Treatment adherence mostly improved, but substance use was reported to decrease in only a third of the studies. Overall functioning improved in about half of the studies. The heterogeneity of the results might be linked to these differences between studies. Further research is needed in the field.

Keywords: case management, assertive community treatment, substance use disorder, substance abuse, alcohol use disorder

\section{INTRODUCTION}

Substance use disorders (SUDs), which include drug abuse, problematic drug use, drug misuse, and substance misuse, are an important health problem (1). Persons with SUDs are characterized by multiple social and medical needs and are often known for their difficulty in engaging in treatment, partly because access to treatment facilities is limited (2). The chronicity and relapsing nature of SUD, as in other psychiatric disorders, entails frequent hospitalizations (3) and readmissions.

Patients presenting both severe mental illnesses and SUD are typically hospitalized more often than are non-substance users $(4,5)$. Patients presenting this double diagnosis also have more difficulties 
entering alcohol and drug outpatient clinics than patients with only SUD (6). This group of patients seems to have less access to aftercare services (7) and higher use of acute services, such as emergency room treatment and hospital services (8).

The period after discharge is characterized by a high risk of relapse, with most cases occurring within the first week of inpatient treatment (9). There is also an important risk of drug-related death (either accidental or intended) following a longer period of abstinence because of lower drug tolerance $(10,11)$. These patients have multiple psychosocial problems for which they need support. Patient needs often remain unmet in current outpatient treatment programs (2), although the provision of help with legal advice, basic needs, and family services may improve patients' psychosocial functioning. Treatment continuity has been related to higher overall abstinence rates $(12,13)$ and less frequent readmissions to hospital units (14). Between hospital and community care, treatment continuity is supposed to improve comprehensive support for patients.

Different strategies have been developed to improve treatment adherence and drug-related outcomes (15); among them, case management (CM) has been identified as potentially beneficial as suggested in early clinical studies (16). The definition of CM and its practice varies from place to place. In general, CM can be defined as a "coordinated integrated approach to service delivery, ongoing supportive care and help to access resources for living and functioning in the community" (17). This approach has been widely implemented in many different areas, such as insurance programs, education, and health care.

Given the complex, chronic, and relapsing nature of mental health disorders and SUDs, they require a broad and continuous approach such as can be offered by CM (17). Since the 1980s, this practice has been adapted for persons with SUD (18), but to date, only a few studies have described CM models for persons with SUD in Europe.

The aim of this study was thus to assess the effectiveness of CM for patients with SUD. We searched for published articles in which clinical CM was described for patients with SUD to help maintain treatment continuity and coordinate care after a patient was discharged from hospital or prison (transitional CM) or when a patient entered a treatment program.

\section{METHOD}

The electronic database PubMed was searched for empirical studies published between January 1996 and May 2016. The following keywords were used: "case management" AND "addiction"; "case management" AND "substance use disorder"; "case management" AND "substance abuse." The inclusion criteria were as follows: randomized controlled trial, adult participants over the age of 18 years with SUD, and a CM intervention compared to treatment as usual (TAU).

\section{RESULTS}

After checking for the inclusion criteria and for duplicates, we analyzed 14 studies (Figure 1). Details about the included studies are described in Table 1. One paper (19) was reviewed but excluded. It compared assertive community treatment to another form of CM intervention. In absence of a TAU comparison group, the study was not included.

The names of CM interventions varied in different studies. They were labeled "intensive," "community," or "assertive CM" (20-22); "strengths-based" (23-26), "clinical" (27), and "transitional CM" (28); or "coordinated care management" (29) and "probation CM" (30). Although the names and interventions varied, certain common characteristics could be found. CM services were conducted by case managers with a professional background in nursing, social work, or mental health care (22). CM services were delivered mainly in the patients' communities and not at the treatment center or hospital (20-22). The length of interventions varied from 1 month (25) to 3 years (20), although 6 months to 1 year was the most common. The intensity of the $\mathrm{CM}$ intervention was rarely noted.

\section{Study Populations}

In some studies, the population had SUD and no further differentiation was made, whereas other studies considered specific subgroups such as patients in methadone programs (27), women with SUD $(22,31,32)$, and participants with court judgments who were either incarcerated or in court-ordered treatments (23, 28, 30). Most studies were done in the United States, except for the one by Prendergast et al. (28) in Canada and Lindhal et al. (23) in Sweden.

\section{Outcome Measures}

The most frequently used outcome measures were change in drug or alcohol use, as well as adherence to SUD treatment (frequently measured in attendance rates) and linkage to other health-care providers. The other important outcome measures were healthcare use in terms of days of hospitalization, emergency ward visits, or health costs. On a more general level, some studies measured global functioning; employment rates; reduction of social, legal, and family problems; and client satisfaction. Two studies concerning incarcerated or court-ordered individuals also used the number of post-enrollment arrests as an outcome measure $(28,30)$.

Most studies considered only SUD as an inclusion criterion. Surprisingly, the importance of comorbid mental health disorders or high service use was not defined as an inclusion criterion in most studies. Slesnick and Erdam's study (32) included only homeless mothers, and Morgenstern et al.s studies (22, 29, 31) analyzed patients receiving welfare [in one study (22), only women were included]. Only Essock et al.s study (20) used high service use, severe comorbid mental health disorder, unstable housing, and poor living skills as inclusion criteria. Some studies even excluded psychotic disorders $(22,24)$, and Morgenstern et al.s study (29) excluded patients who had been hospitalized more than once for mental health reasons in the past year.

\section{Effect of the Intervention}

Only two studies $(28,30)$ did not find any additional value in $\mathrm{CM}$ when treating addicted patients. The other 12 papers found significant improvement of some or all the outcome measures. These improvements were not the same for each survey. 


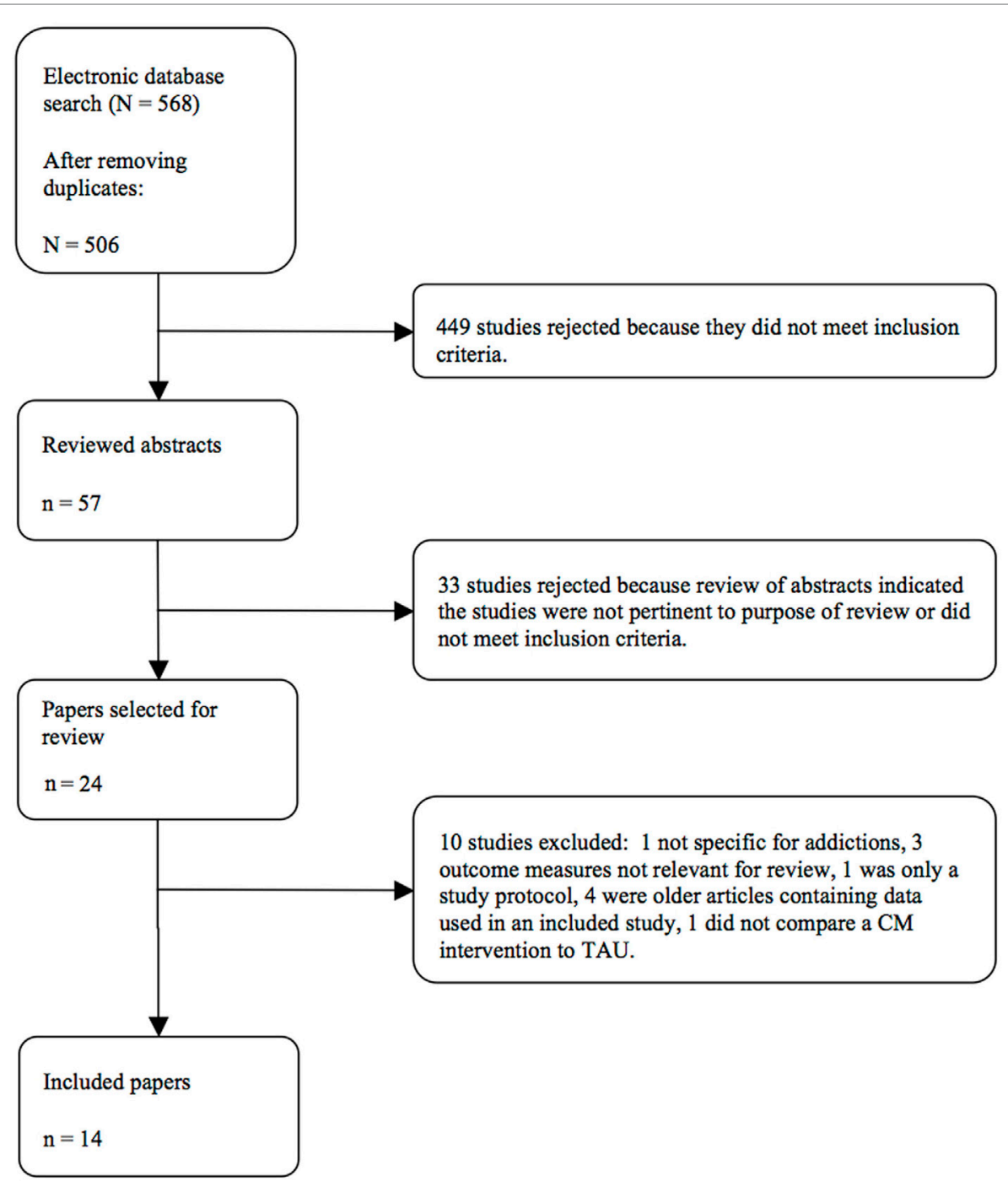

FIGURE 1 | Study flow diagram

Five studies showed that substance use decreased $(20,22$, $23,27,32)$, two papers $(22,26)$ showed that the likelihood of initiating SUD treatment increased, and four publications (22, $23,27,33$ ) showed greater treatment retention when a case manager was involved in treatment. Four studies $(23,24,33,34)$ showed improved access to health care and/or linkage between health-care providers. One research showed fewer days spent in hospital (20) but others reported an increased number of days in hospital, which is explained by the higher treatment retention (34). Seven publications showed better global functioning, which was described as more employment days (25, 31, 35). This was further differentiated in Morgenstern et al.s study of 2008 (29), which showed that women were more likely than men to find employment when assisted by CM, to have fewer legal $(21,35)$ and family problems (21), and to have better housing stability (32). Lindahl et al. measured very high patient satisfaction with the treatment and $100 \%$ treatment retention compared to TAU (23).

\section{DISCUSSION}

In most studies, significant improvements were reported in the outcome measures. Substance use decreased in only five papers $(20,22,23,27,32)$, but treatment adherence and linkage between health-care providers seemed to improve in most surveys, which is an important issue for this population and one of the main aims of CM. Overall functioning improved in more than half of the studies, which is in general linked to higher life satisfaction.

The two publications $(28,30)$ that did not find significant improvements in one of the outcome measures were both performed with incarcerated or paroled patients. In Guydish et al.'s paper (30), the important factor was the limited face-to-face time. Only 53.6\% of participants had seen their CM once or more during the first 6 months. For those participants who had seen their CM two or more times in the first 6 months, there was an improvement in substance use and social problems. This finding shows how important treatment intensity of CM is for the outcome. The 
TABLE 1 | Characteristics of the included studies.

Reference, Target population

Number of Contro

CM interventions/dose of $\mathrm{CM}$

Outcome

measures

Guydish et al. Drug-involved women $N=183 \quad$ TAU $=$ standard

12 months of PCM involving

offenders on probation IG: $n=92$; probation

or awaiting probation

uniform assessment procedures,

a therapeutic and advocacy

ASI, BDI, BS

Follow-up Results

(a)

orientation, treatment planning

Social Support

Evaluation List,

counseling, and home visits.

service utilization,

enter a substance

Dosage: at least two contacts per 12 months of face

arrest during

Essock et al. Alcohol and illicit

drug users with a

co-occurring major

psychotic disorder,

who had high service

use in the past 2 years,

were homeless or

unstably housed, and

had poor living skills

$\begin{array}{ll}N=198 & \text { Standard } \\ \text { IG: } n=99 ; & \text { clinical CM: } \\ \text { CG: } n=99 & \text { comprehensive } \\ & \text { assessment, } \\ & \text { individual MI, } \\ & \text { group treatments, } \\ & \text { and stage-wise } \\ & \text { interventions }\end{array}$

Three years of community-based assertive CM treatment: direct

time with $\mathrm{CM}$

6 and Proportion of women enrolled in SUD treatment or incarcerated

12 months was not statistically different for both groups. All other measures were not statistically different between groups. At 6 months,

$53.6 \%$ of PCM participants met face-to-face with case manager

once or more and at 12 months $43.5 \%$ did. In CG, this was 11.6 and $8.5 \%$, respectively. This shows that the dosage was often a

lot less than twice a month, as described in the intervention. The participants who had two or more contacts with case manager were more likely to have lower ASI rates and lower social severity rates

Substance use Ever

(days of use,

Participants in both treatment conditions improved over time

substance abuse treatment by

ASI, toxicology

6 months in multiple outcome domains, and few differences were found

ase managers and comprehensive screens) structured assessment, individual Ml, group

interview and ratin scales assessed

interventions. Case managers had

half the patient load that they had for $C G$

by case manager

rates; Quality of

Life Interview; CM

dosage: contacts

per month with

case manager

in models. Decreases in substance use were

greater than would be expected given time alone. At the site

that had higher rates of institutionalization, clients who received

standard CM were more likely to be institutionalized. However, in

the site that had lower rates of institutionalization, no differences

in the rate of institutionalization were found between the two treatment conditions. At one site, the IG received a significantly higher dose (time and activities) of services than did the CG. At the other site, the difference was not significant. Integrated treatment can be successfully delivered either by assertive

community treatment or by standard clinical $\mathrm{CM}$

Huber et al. Drug or alcohol users who were diagnosed

Community-based comprehensive

CM dosage, AS

3,6 , and

Clients who engaged (actively participated) in CM were less with substance abuse

IG: $n=437$

CM intervention: 12 months of

disorder and enrolled

CM interventions consisted

four $\mathrm{CM}$ conditions with a case

manager working as a member

of drug-treatment staff (inside),

treatment facility

a case manager from an outside

social service agency (outside), or a

case manager using computerized

telecommunication (telecom). CG

received standard drug abuse

treatment. Five types of $\mathrm{CM}$

interventions were assessing

individual solution planning, referral,

advocating, and conferencing significantly across treatment conditions. In general, dose was significantly related to outcomes in the legal and family domains 
TABLE 1 | Continued

\begin{tabular}{|c|c|c|c|c|c|c|c|}
\hline $\begin{array}{l}\text { Reference, } \\
\text { country }\end{array}$ & Target population & $\begin{array}{l}\text { Number of } \\
\text { subjects }\end{array}$ & $\begin{array}{l}\text { Control } \\
\text { intervention }\end{array}$ & $\mathrm{CM}$ interventions/dose of $\mathrm{CM}$ & $\begin{array}{l}\text { Outcome } \\
\text { measures }\end{array}$ & Follow-up & Results \\
\hline \multirow{2}{*}{$\begin{array}{l}\text { Lindahl et al. } \\
\text { (23), Sweden } \\
\text { (EU) }\end{array}$} & \multirow{2}{*}{$\begin{array}{l}\text { Court-ordered } \\
\text { substance abuse } \\
\text { patients }\end{array}$} & $N=34$ & \multirow[t]{2}{*}{ TAU } & \multirow{2}{*}{$\begin{array}{l}\text { Six months of CM intervention: case } \\
\text { managers offered assessment, } \\
\text { transitional care, support of referral } \\
\text { services, and intervention to avoid } \\
\text { crisis }\end{array}$} & \multirow[b]{2}{*}{$\begin{array}{l}\text { Substance use } \\
\text { (ASI, AUDIT, } \\
\text { AUDRUG, SIP, } \\
\text { days of } \\
\text { alcohol used); } \\
\text { psychological } \\
\text { functioning; } \\
\text { involuntary } \\
\text { care (coercive } \\
\text { measures); } \\
\text { number of days } \\
\text { in institutional or } \\
\text { hospital care was } \\
\text { measured }\end{array}$} & \multirow{2}{*}{$\begin{array}{l}6 \text { and } \\
12 \text { months } \\
\text { after } \\
\text { discharge }\end{array}$} & \multirow[b]{2}{*}{$\begin{array}{l}\text { More patients from the CM group were abstinent compared with } \\
\text { those in the CG at the first follow-up at } 6 \text { months ( } 46 \text { vs. } 14 \% \text {, } \\
p<0.051) \text {. } \\
\text { Patients in the CM group did not have more contact with health } \\
\text { and social services ( } 92 \% \text { ) compared with those in the CG }(76 \%) \\
(p=0.23) \text {, nor did they have more medical-assisted treatment } \\
(p=0.46 \text { ) or institutional/inpatient care }(p=0.27 \text { ) to a higher } \\
\text { degree than patients in the CG. } \\
C M \text { interventions were well received by the patients with no } \\
\text { dropout during intervention. Patients with the support of a case } \\
\text { manager seemed to sustain abstinence to a higher degree } \\
\text { compared with TAU, but no differences were detected regarding } \\
\text { use of care. A subgroup analysis showed that patients with } \\
\text { continuous drug abuse had access to care from both social } \\
\text { welfare and hospital care systems }\end{array}$} \\
\hline & & $\begin{array}{l}\text { IG: } n=13 \\
\text { CG: } n=21\end{array}$ & & & & & \\
\hline \multirow[b]{2}{*}{$\begin{array}{l}\text { Morgenstern } \\
\text { et al. (22), } \\
\text { USA } \\
\text { Morgenstern } \\
\text { et al. (31): } \\
\text { 24-month } \\
\text { outcome }\end{array}$} & \multirow[b]{2}{*}{$\begin{array}{l}\text { Women with SUD } \\
\text { receiving temporary } \\
\text { assistance for needy } \\
\text { families; not psychotic, } \\
\text { under methadone } \\
\text { treatment or seeking } \\
\text { methadone treatment, } \\
\text { or already in treatment } \\
\text { program }\end{array}$} & $N=302$ & \multirow[b]{2}{*}{$\begin{array}{l}\text { TAU, which } \\
\text { was standard } \\
\text { substance abuse } \\
\text { screening and } \\
\text { referral system } \\
\text { within welfare } \\
\text { department }\end{array}$} & \multirow[b]{2}{*}{$\begin{array}{l}\text { ICM intervention: CM services were } \\
\text { provided throughout the 15-month } \\
\text { follow-up period; assessment, } \\
\text { planning, motivational enhancement, } \\
\text { treatment coordination, peer } \\
\text { support, and crisis management. If } \\
\text { needed, case managers provided } \\
\text { home visiting services. Contact was } \\
\text { adapted to needs from daily to two } \\
\text { visits per month }\end{array}$} & \multirow[b]{2}{*}{$\begin{array}{l}\text { Substance use } \\
\text { (ASI, toxicology } \\
\text { screen). Treatment } \\
\text { attendance. } \\
\text { Treatment } \\
\text { engagement. } \\
\text { Treatment retention } \\
\text { rate }\end{array}$} & \multirow{2}{*}{$\begin{array}{l}3,9 \text {, and } \\
15 \text { months; } \\
24 \text { months } \\
\text { (article 28) }\end{array}$} & \multirow[b]{2}{*}{$\begin{array}{l}\text { ICM clients had significantly higher levels of substance abuse } \\
\text { treatment initiation, engagement, and retention compared with } \\
\text { CG clients. In some cases, ICM treatment attendance rates were } \\
\text { double those of CG rates. Additionally, almost twice as many } \\
\text { ICM clients were abstinent at the } 15 \text {-month follow-up compared } \\
\text { with CG clients }(p<0.0025) \text {. After } 24 \text { months, abstinence rates } \\
\text { were higher in the ICM group than they were for usual care. } \\
\text { Additionally, there were greater odds of being employed full time }\end{array}$} \\
\hline & & $\begin{array}{l}\text { IG: } n=161 \\
\text { CG: } n=141\end{array}$ & & & & & \\
\hline \multirow{2}{*}{$\begin{array}{l}\text { Morgenstern } \\
\text { et al. (29), } \\
\text { USA }\end{array}$} & \multirow{2}{*}{$\begin{array}{l}\text { SUD welfare applicants } \\
\text { without acute } \\
\text { psychotic symptoms } \\
\text { and not more than } \\
\text { one hospitalization for } \\
\text { mental health problems } \\
\text { in the last year }\end{array}$} & $\begin{array}{l}N=394 \\
(66 \% \text { men })\end{array}$ & \multirow[t]{2}{*}{ Usual care } & \multirow{2}{*}{$\begin{array}{l}\text { CCM: continuity of care intervention } \\
\text { focused on engaging clients in drug } \\
\text { treatment, linking to needed ancillary } \\
\text { services, and fostering transition } \\
\text { to employment. Biweekly visit at } \\
\text { treatment center and regular contact } \\
\text { in office or by phone }\end{array}$} & \multirow{2}{*}{$\begin{array}{l}\text { Employment } \\
\text { outcomes (days of } \\
\text { employment and } \\
\text { percentage of full- } \\
\text { time employment), } \\
\text { abstinence } \\
\text { rates, treatment } \\
\text { attendance }\end{array}$} & \multirow[t]{2}{*}{$\begin{array}{l}\text { 1-year } \\
\text { follow-up }\end{array}$} & \multirow{2}{*}{$\begin{array}{l}\text { Overall, men were more likely to work than women. There } \\
\text { was no difference between groups. CCM increased women's } \\
\text { employment over time. Among women only, greater SUD } \\
\text { treatment attendance and abstinence in the first } 6 \text { months of } \\
\text { CCM predicted higher rates of later employment }\end{array}$} \\
\hline & & $\begin{array}{l}\text { IG: } n=221 \\
\text { CG: } n=173\end{array}$ & & & & & \\
\hline \multirow{2}{*}{$\begin{array}{l}\text { Plater-Zyberk } \\
\text { et al. (27), } \\
\text { ON, Canada }\end{array}$} & \multirow{2}{*}{$\begin{array}{l}\text { Patients enrolled } \\
\text { in a methadone } \\
\text { maintenance treatment } \\
\text { program }\end{array}$} & $N=1,704$ & \multirow{2}{*}{$\begin{array}{l}\text { TAU: standard } \\
\text { outpatient } \\
\text { treatment }\end{array}$} & \multirow{2}{*}{$\begin{array}{l}\text { Clinical CM: duration and frequency } \\
\text { varied according to clients' needs }\end{array}$} & \multirow[b]{2}{*}{$\begin{array}{l}\text { Drug-positive urine } \\
\text { samples, missed } \\
\text { daily methadone } \\
\text { doses, missed } \\
\text { methadone } \\
\text { physician } \\
\text { appointments }\end{array}$} & \multirow[t]{2}{*}{3 months } & \multirow{2}{*}{$\begin{array}{l}\text { The IG demonstrated statistically significant improvement in } \\
\text { all three measures of the methadone maintenance treatment } \\
\text { program. Less drug-positive urine: } 15.4 \% \text { relative reduction. } \\
\text { Fewer missed daily methadone doses: } 2 \% \text { relative reduction. } \\
\text { Fewer missed appointments with the methadone physician: } 40 \% \\
\text { relative reduction }\end{array}$} \\
\hline & & $\begin{array}{l}\text { IG: } n=396 \text {; } \\
\text { CG: } \\
n=1,308\end{array}$ & & & & & \\
\hline
\end{tabular}


TABLE 1 | Continued

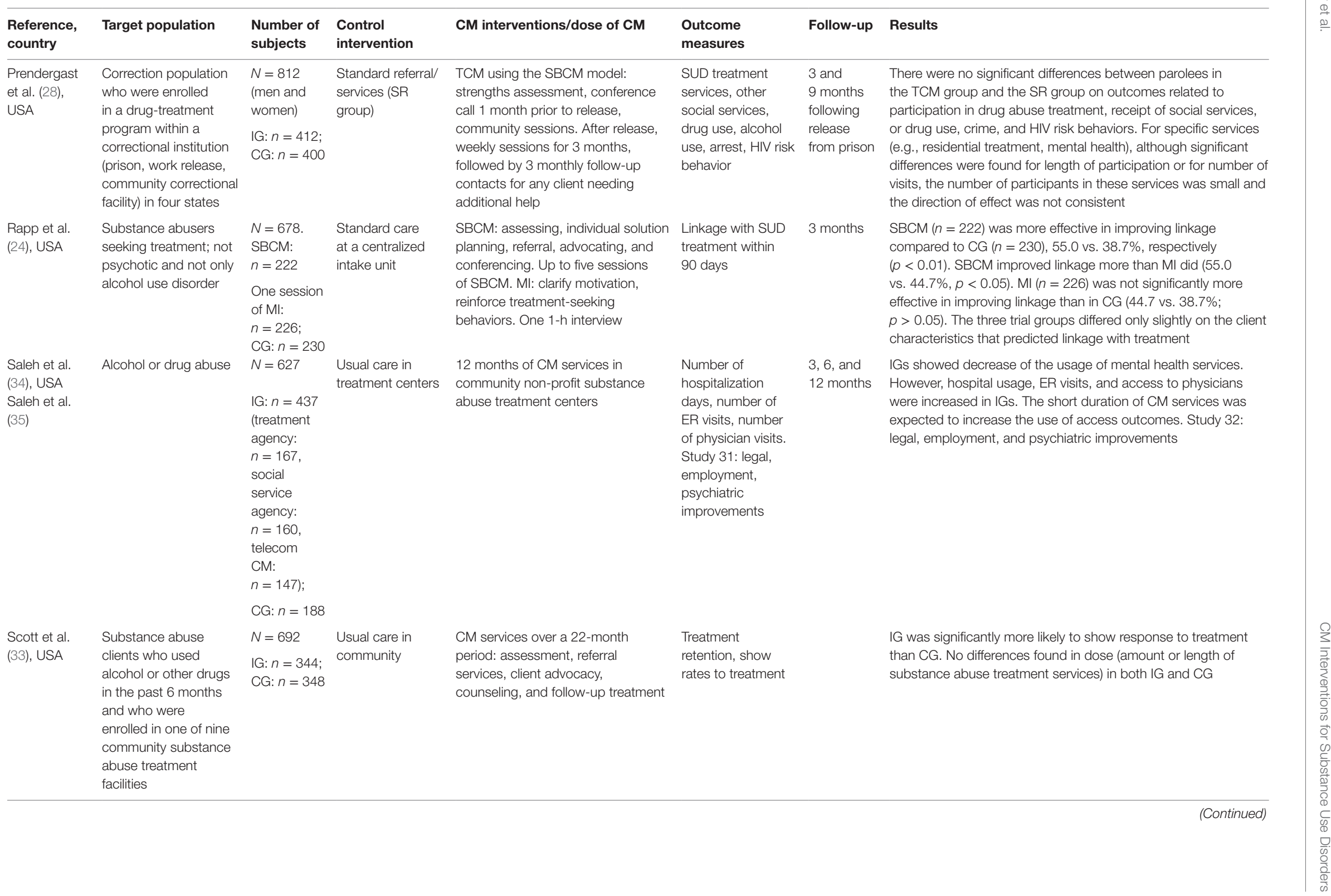


TABLE 1 | Continued

\begin{tabular}{|c|c|c|c|c|c|c|c|}
\hline $\begin{array}{l}\text { Reference, } \\
\text { country }\end{array}$ & Target population & $\begin{array}{l}\text { Number of } \\
\text { subjects }\end{array}$ & $\begin{array}{l}\text { Control } \\
\text { intervention }\end{array}$ & $\mathrm{CM}$ interventions/dose of $\mathrm{CM}$ & $\begin{array}{l}\text { Outcome } \\
\text { measures }\end{array}$ & Follow-up & Results \\
\hline $\begin{array}{l}\text { Siegal et al. } \\
\text { (25), USA }\end{array}$ & $\begin{array}{l}\text { Veterans seeking } \\
\text { treatment for } \\
\text { substance abuse } \\
\text { problems }\end{array}$ & $\begin{array}{l}N=632 \\
\text { CM: } \\
n=313 \\
\text { CG: } n=319\end{array}$ & CG: no CM group & $\begin{array}{l}\text { Veterans in the inpatient component } \\
\text { participate in three phases lasting a } \\
\text { total of } 28 \text { days. Outpatients attend } \\
10 \text { weeks of sessions involving } \\
\text { education about substance abuse } \\
\text { problems and group therapy } \\
\text { sessions designed to assist in } \\
\text { achieving abstinence. Both inpatient } \\
\text { and outpatient clients are referred } \\
\text { to an aftercare service upon } \\
\text { completion of primary treatment. } \\
\text { The clients in the IG received } \\
\text { help for strengths assessment, } \\
\text { identifying goals, and, if appropriate, } \\
\text { accompaniment on job search }\end{array}$ & $\begin{array}{l}\text { Substance use } \\
\text { (ASI), psychosocial } \\
\text { functioning, } \\
\text { employment } \\
\text { outcomes }\end{array}$ & 6 months & $\begin{array}{l}\text { All clients showed significant improvement in employment } \\
\text { outcomes, an increase of } 6 \text { days worked }(p<0.01) \text { in the last } \\
30 \text { days before the } 3 \text {-month follow-up. SBCM reported } 3.5 \\
\text { additional days worked compared to non-case-managed clients. } \\
\text { There was a positive relationship between improved employment } \\
\text { functioning and improvement in other life areas }\end{array}$ \\
\hline $\begin{array}{l}\text { Slesnick and } \\
\text { Erdem (32), } \\
\text { USA }\end{array}$ & $\begin{array}{l}\text { Substance-abusing } \\
\text { homeless mothers with } \\
\text { a 2- to 6-year-old child }\end{array}$ & $\begin{array}{l}N=60 \\
\text { IG: } n=30 \\
\text { CG: } n=30\end{array}$ & $\begin{array}{l}\text { Usual care in } \\
\text { community }\end{array}$ & $\begin{array}{l}\text { Ecologically based treatment with } \\
\text { CM services. The mothers were } \\
\text { housed in apartments of their } \\
\text { choosing and received } 3 \text { months } \\
\text { of utility and rental assistance. CM } \\
\text { services for } 6 \text { months, focusing } \\
\text { on basic needs (i.e., referrals } \\
\text { to food pantries); assisting, } \\
\text { obtaining government entitlements; } \\
\text { employment; connecting to social } \\
\text { services; providing referrals and/ } \\
\text { or transportation to appointments. } \\
\text { Average of } 23.1 \text { sessions in } \\
6 \text { months }\end{array}$ & $\begin{array}{l}\text { Substance use, } \\
\text { retention rate, } \\
\text { independent living } \\
\text { days }\end{array}$ & $\begin{array}{l}3,6 \text {, and } \\
9 \text { months }\end{array}$ & $\begin{array}{l}\text { Mothers receiving ecologically based treatment showed a } \\
\text { high retention rate on treatment, a faster decline in alcohol use } \\
(p<0.05) \text {, and a faster increase in their independent living days } \\
(p<0.001) \text {. Furthermore, with supportive services, two-thirds } \\
\text { of women were successful in maintaining their apartments } \\
6 \text { months after rental assistance ended. However, no treatment } \\
\text { effects were found in drug use }(p>0.05)\end{array}$ \\
\hline $\begin{array}{l}\text { Strathdee } \\
\text { et al. (26), } \\
\text { USA }\end{array}$ & $\begin{array}{l}\text { Clients of the Baltimore } \\
\text { Needle Exchange } \\
\text { Program who sought } \\
\text { drug abuse treatment }\end{array}$ & $\begin{array}{l}N=245 \\
\text { IG: } n=128 \\
\text { CG: } n=117\end{array}$ & $\begin{array}{l}\text { Passive referral } \\
\text { [voucher printed } \\
\text { with date, time, } \\
\text { and location } \\
\text { for intake } \\
\text { appointment } \\
\text { (of opioid } \\
\text { agonist) at the } \\
\text { drug-treatment } \\
\text { program] }\end{array}$ & $\begin{array}{l}\text { SBCM: engagement, strengths } \\
\text { assessment, personal case } \\
\text { planning, resource acquisition. } \\
\text { The duration and frequency of CM } \\
\text { contacts were client-driven, based } \\
\text { on individual desires and needs }\end{array}$ & $\begin{array}{l}\text { Intake appointment } \\
\text { for opioid agonist } \\
\text { therapy within } \\
7 \text { days }\end{array}$ & 7 days & $\begin{array}{l}\text { In a multivariate "intention-to-treat" model (i.e., ignoring the } \\
\text { amount of CM actually received), those randomized to CM were } \\
\text { more likely to enter treatment within } 7 \text { days ( } 40 \text { vs. control: } \\
26 \%, p=0.03 \text { ). Additional "as-treated" analyses revealed that } \\
\text { participants who received } 30 \text { min or more of CM within } 7 \text { days } \\
\text { were } 33 \% \text { more likely to enter treatment. The active ingredient of } \\
\text { CM activities was provision of transportation }\end{array}$ \\
\hline
\end{tabular}

CM, case management; SUD, substance use disorder; IG, intervention group; CG, control group; PCM, probation case management; TAU, treatment as usual; ASI, Addiction Severity Index; BDI, Beck Depression Inventory; BSI, Brief Symptom Inventory; AUDIT, Alcohol Use Disorders Identification Test; AUDRUG, Drug Use Identification Test; SIP, Short Index of Problems; ICM, intensive case management; CCM, coordinated care management; SR, standard referral; TCM, transitional case management; SBCM, strengths-based case management; MI, motivational interviewing; ER, emergency room. 
other study with a negative outcome, by Prendergast et al. (28), showed no improvement in treatment participation for parolees with SUD who were receiving CM. However, this finding cannot be generalized, as the case manager's adherence to the protocol and the intervention was not standardized. Moreover, the case manager seemed to have limited contact with the parolee and the parolees did not enroll voluntarily in the project.

The studies are heterogeneous in their clinical approach, which limits our ability to generalize specific implications for practice. Different types of populations with different risk levels seem to account for the variation in readmission rates (36). For example, the study populations varied in illness severity (comorbidities and service use), which would most likely have an effect on the study outcome. Some comorbid populations were also excluded from surveys. The CM model is a specific intervention that seems more useful to specific subgroups who are unable to use existing health-care services. A large number of patients find adequate health care in the usual care programs, as shown in research on $\mathrm{CM}$ interventions that involve psychiatric patients with psychosis. Patients who benefit from CM have been shown to be those with greater social and psychosocial needs, more psychiatric symptoms, and higher service use (37), with others not needing this specific intensive care (38). If CM is applied to a large group, the effect on a smaller subgroup would likely be diluted and not as visible in the outcome measures. It will be important to further specify these subgroups in future in order to refer patients to the appropriate programs.

The intensity of application of CM differs in these studies, which also limits our ability to generalize the effects (39). These examples show the importance of face-to-face time with patients, which can be managed only with small caseloads. This seems to have been a limiting factor in the two studies $(28,30)$ mentioned above. In addition, the adherence to the model by the case manager and the voluntary participation of the patients seem to affect the outcome.

The majority of the studies were performed in the United States, which is a limiting factor in generalizing these findings

\section{REFERENCES}

1. Degenhardt L, Hall W. Extent of illicit drug use and dependence, and their contribution to the global burden of disease. Lancet (2012) 379:55-70. doi:10.1016/S0140-6736(11)61138-0

2. Pringle JL, Emptage NP, Hubbard RL. Unmet needs for comprehensive services in outpatient addiction treatment. J Subst Abuse Treat (2006) 30:183-9. doi:10.1016/j.jsat.2005.11.006

3. Bonsack C, Gibellini S, Ferrari P, Dorogi Y, Morgan C, Morandi S, et al. Le case management de transition: Une intervention à court terme dans la communauté après une hospitalisation psychiatrique. Schweiz Arch Neurol Psychiatr (1985) (2009) 160:246-52.

4. Bartels SJ, Teague GB, Drake RE, Clark RE, Bush PW, Noordsy DL. Substance abuse in schizophrenia: service utilization and costs. J Nerv Ment Dis (1993) 181:227-32. doi:10.1097/00005053-199304000-00003

5. Cuffel BJ, Chase P. Remission and relapse of substance use disorders in schizophrenia. Results from a one-year prospective study. J Nerv Ment Dis (1994) 182:342-8. doi:10.1097/00005053-199406000-00006

6. Narrow WE, Regier DA, Rae DS, Manderscheid RW, Locke BZ. Use of services by persons with mental and addictive disorders: findings from the National Institute of Mental Health Epidemiologic Catchment Area Program. Arch Gen Psychiatry (1993) 50:95-107. doi:10.1001/archpsyc.1993. 01820140017002 to other countries such as those in Europe, where health systems differ in organization and funding. A further limitation of this research was that the data search was performed only on the PubMed database and possibly that unpublished negative studies were not taken into account. Furthermore, we did not differentiate between alcohol use disorder and other SUDs.

\section{CONCLUSION}

Most of the analyzed studies showed improvement in the chosen outcome measures, although these varied in different studies. Treatment adherence mostly improved, but substance use decreased in only a third of the studies. Overall functioning improved in about half of the studies. The differences in chosen outcome measures make it difficult to compare the results. The type of intervention and intensity of treatment also varied.

The heterogeneity of these results might be linked to the different types of populations studied. The specific CM intervention seems to be helpful only for specific subpopulations with SUDs. Further studies are necessary to determine inclusion criteria for CM treatment for patients with SUD in order to orientate those most likely to benefit from this approach to the specific CM programs.

Only a few studies on this intervention and SUD have been published. Further research is needed to examine the effect of treatment intensity of the CM intervention. Longitudinal studies are also needed in Europe to ensure the effectiveness of these treatments.

\section{AUTHOR CONTRIBUTIONS}

LP, AM, and YK designed the strategy for the present review and drafted the manuscript. AM and LP searched for the references and read the manuscripts. LP, AM, and YK discussed the results. All authors reviewed the manuscript and helped with the final writing.

7. Haugland G, Siegel C, Alexander MJ, Galanter M. A survey of hospitals in New York State treating psychiatric patients with chemical abuse disorders. Psychiatr Serv (1991) 42:1215-20. doi:10.1176/ps.42.12.1215

8. Havassy BE, Shopshire MS, Quigley LA. Effects of substance dependence on outcomes of patients in a randomized trial of two case management models. Psychiatr Serv (2000) 51:639-44. doi:10.1176/appi.ps.51.5.639

9. Smyth BP, Barry J, Keenan E, Ducray K. Lapse and relapse following inpatient treatment of opiate dependence. Ir Med J (2010) 103:176-9.

10. Ravndal E, Amundsen EJ. Mortality among drug users after discharge from inpatient treatment: an 8-year prospective study. Drug Alcohol Depend (2010) 108:65-9. doi:10.1016/j.drugalcdep.2009.11.008

11. Merrall EL, Bird SM, Hutchinson SJ.A record-linkage study of drugrelated death and suicide after hospital discharge among drug-treatment clients in Scotland, 1996-2006. Addiction (2013) 108:377-84. doi:10.1111/j. 1360-0443.2012.04066.x

12. Schaefer JA, Harris AH, Cronkite RC, Turrubiartes P. Treatment staff's continuity of care practices, patients' engagement in continuing care, and abstinence following outpatient substance-use disorder treatment. J Stud Alcohol Drugs (2008) 69:747-56. doi:10.15288/jsad.2008.69.747

13. Parmenter J, Mitchell C, Keen J, Oliver P, Rowse G, Neligan I, et al. Predicting biopsychosocial outcomes for heroin users in primary care treatment: a prospective longitudinal cohort study. Br J Gen Pract (2013) 63:e499-505. doi:10.3399/bjgp13X669220 
14. Raven MC, Carrier ER, Lee J, Billings JC, Marr M, Gourevitch MN. Substance use treatment barriers for patients with frequent hospital admissions. J Subst Abuse Treat (2010) 38:22-30. doi:10.1016/j.jsat.2009.05.009

15. Broekaert E, Vanderplasschen W. Towards the integration of treatment systems for substance abusers: report on the second International Symposium on Substance Abuse Treatment and Special Target Groups. J Psychoactive Drugs (2003) 35:237-45. doi:10.1080/02791072.2003.10400005

16. McLellan AT, Hagan TA, Levine M, Meyers K, Gould F, Bencivengo M, et al. Does clinical case management improve outpatient addiction treatment. Drug Alcohol Depend (1999) 55:91-103. doi:10.1016/S0376-8716(98)00183-5

17. Vanderplasschen W, Rapp RC, WolfJR, Broekaert E. The development and implementation of case management for substance use disorders in North America and Europe. Psychiatr Serv (2004) 55:913-22. doi:10.1176/appi.ps.55.8.913

18. Graham K, Timney CB. Case management in addictions treatment. J Subst Abuse Treat (1990) 7:181-8. doi:10.1016/0740-5472(90)90020-Q

19. Clark RE, Teague GB, Ricketts SK, Bush PW, Xie H, McGuire TG, et al. Costeffectiveness of assertive community treatment versus standard case management for persons with co-occurring severe mental illness and substance use disorders. Health Serv Res (1998) 33:1285-308.

20. Essock SM, Mueser KT, Drake RE, Covell NH, McHugo GJ, Frisman LK, et al. Comparison of ACT and standard case management for delivering integrated treatment for co-occurring disorders. Psychiatr Serv (2006) 57:185-96. doi:10.1176/appi.ps.57.2.185

21. Huber DL, Sarrazin MV, Vaughn T, Hall JA. Evaluating the impact of case management dosage. Nurs Res (2003) 52:276-88. doi:10.1097/00006199200309000-00002

22. Morgenstern J, Blanchard KA, McCrady BS, McVeigh KH, Morgan TJ, Pandina RJ. Effectiveness of intensive case management for substancedependent women receiving temporary assistance for needy families. Am J Public Health (2006) 96:2016-23. doi:10.2105/AJPH.2005.076380

23. Lindahl ML, Berglund $\mathrm{M}$, Tonnesen $\mathrm{H}$. Case management in aftercare of involuntarily committed patients with substance abuse. A randomized trial. Nord J Psychiatry (2013) 67:197-203. doi:10.3109/08039488.2012.704068

24. Rapp RC, Otto AL, Lane DT, Redko C, McGatha S, Carlson RG. Improving linkage with substance abuse treatment using brief case management and motivational interviewing. Drug Alcohol Depend (2008) 94:172-82. doi:10.1016/j.drugalcdep.2007.11.012

25. Siegal HA, Fisher JH, Rapp RC, Kelliher CW, Wagner JH, O’Brien WF, et al. Enhancing substance abuse treatment with case management. Its impact on employment. J Subst Abuse Treat (1996) 13:93-8. doi:10.1016/0740-5472(96)00029-3

26. Strathdee SA, Ricketts EP, Huettner S, Cornelius L, Bishai D, Havens JR, et al. Facilitating entry into drug treatment among injection drug users referred from a needle exchange program: results from a community-based behavioral intervention trial. Drug Alcohol Depend (2006) 83:225-32. doi:10.1016/j. drugalcdep.2005.11.015

27. Plater-Zyberk CJ, Varenbut M, Daiter J, Worster A. The value of clinical case management in a methadone maintenance treatment program. Am JDrug Alcohol Abuse (2012) 38:70-2. doi:10.3109/00952990.2011.600391

28. Prendergast M, Frisman L, Sacks JY, Staton-Tindall M, Greenwell L, Lin HJ, et al. A multi-site, randomized study of strengths-based case management with substance-abusing parolees. J Exp Criminol (2011) 7:225-53. doi:10.1007/ s11292-011-9123-y

29. Morgenstern J, Hogue A, Dauber S, Dasaro C, McKay JR. Does coordinated care management improve employement for substance-using welfare recipients? J Stud Alcohol Drugs (2009) 70:955-63.

30. Guydish J, Chan M, Bostrom A, Jessup M, Davis T, Marsh C. A randomized trial of probation case management for drug-involved women offenders. Crime Delinq (2011) 57:167-98. doi:10.1177/0011128708318944

31. Morgenstern J, Neighbors CJ, Kuerbis A, Riordan A, Blanchard KA, McVeigh KH, et al. Improving 24-month abstinence and employment outcomes for substance-dependent women receiving temporary assistance for needy families with intensive case management. Am J Public Health (2009) 99:328-33. doi:10.2105/AJPH.2007.133553

32. Slesnick N, Erdem G. Efficacy of ecologically-based treatment with substanceabusing homeless mothers: substance use and housing outcomes. J Subst Abuse Treat (2013) 45:416-25. doi:10.1016/j.jsat.2013.05.008

33. Scott CK, Sherman RE, Foss MA, Godley M, Hristova L. Impact of centralized intake on case management services. J Psychoactive Drugs (2002) 34:51-7. doi:10.1080/02791072.2002.10399936

34. Saleh SS, Vaughn T, Hall J, Levey S, Fuortes L, Uden-Holmen T. The effect of case management in substance abuse on health services use. Care Manag J (2003) 4:82-7.

35. Saleh SS, Vaughn T, Hall J, Levey S, Fuortes L, Uden-Holmen T. Effectiveness of case management in substance abuse treatment. Care Manag J (2002) 3:172-7. doi:10.1891/cmaj.3.4.172.57448

36. Vigod SN, Taylor VH, Fung K, Kurdyak PA. Within-hospital readmission: an indicator of readmission after discharge from psychiatric hospitalization. Can J Psychiatry (2013) 58:476-81. doi:10.1177/070674371305800806

37. Mas-Expósito L, Amador-Campos JA, Gómez-Benito J, Lalucat-Jo L. Considering variables for the assignment of patients with schizophrenia to a case management programme. Community Ment Health J (2013) 49:831-40. doi:10.1007/s10597-013-9621-7

38. Alameda L, Golay P, Baumann P, Morandi S, Ferrari C, Conus P, et al. Assertive outreach for "difficult to engage" patients: a useful tool for a subgroup of patients in specialized early psychosis intervention programs. Psychiatry Res (2016) 239:212-9. doi:10.1016/j.psychres.2016.03.010

39. Joo JY, Huber DL. Community-based case management effectiveness in populations that abuse substances. Int Nurs Rev (2015) 62:536-46. doi:10.1111/ inr.12201

Conflict of Interest Statement: The authors declare that the research was conducted in the absence of any commercial or financial relationships that could be construed as a potential conflict of interest.

Copyright (c) 2017 Penzenstadler, Machado, Thorens, Zullino and Khazaal. This is an open-access article distributed under the terms of the Creative Commons Attribution License (CC BY). The use, distribution or reproduction in other forums is permitted, provided the original author(s) or licensor are credited and that the original publication in this journal is cited, in accordance with accepted academic practice. No use, distribution or reproduction is permitted which does not comply with these terms. 